Article

\title{
Anti-Inflammatory Lobane and Prenyleudesmane Diterpenoids from the Soft Coral Lobophytum varium
}

\author{
Atallah F. Ahmed ${ }^{1,2,3,+} \mathbb{B}^{\mathbb{D}}$, Wan-Ting Teng ${ }^{1,+}$, Chiung-Yao Huang ${ }^{1,+}$, Chang-Feng Dai ${ }^{4}$, \\ Tsong-Long Hwang ${ }^{5,6,7}$ and Jyh-Horng Sheu 1,8,9,10,11,* \\ 1 Department of Marine Biotechnology and Resources, National Sun Yat-sen University, Kaohsiung 804, \\ Taiwan; afahmed@ksu.edu.sa (A.F.A.); m025020024@student.nsysu.edu.tw (W.-T.T.); \\ huangcy@mail.nsysu.edu.tw (C.-Y.H.) \\ 6 Research Center for Chinese Herbal Medicine, Research Center for Food and Cosmetic Safety, and Graduate \\ Institute of Health Industry Technology, College of Human Ecology,

Received: 29 August 2017; Accepted: 27 September 2017; Published: 29 September 2017

\begin{abstract}
New lobane-based diterpenoids lobovarols A-D (1-4) and a prenyleudesmane-type diterpenoid lobovarol E (5) along with seven known related diterpenoids (6-12) were isolated from the ethyl acetate extract of a Taiwanese soft coral Lobophytum varium. Their structures were identified on the basis of multiple spectroscopic analyses and spectral comparison. The absolute configuration at C-16 of the known compound $\mathbf{1 1}$ is reported herein for the first time. The anti-inflammatory activities of compounds 1-12 were assessed by measuring their inhibitory effect on $N$-formyl-methionyl-leucyl-phenyl-alanine/cytochalasin B (fMLP/CB)-induced superoxide anion generation and elastase release in human neutrophils. Metabolites 2, 5, and $\mathbf{1 1}$ were found to show moderate inhibitory activity on the generation of superoxide anion, while compounds $5,8,11$, and 12 could effectively suppress elastase release in fMLP/CB-stimulated human neutrophil cells at $10 \mu \mathrm{M}$. All of the isolated diterpenoids did not exhibit cytotoxic activity $\left(\mathrm{IC}_{50}>50 \mu \mathrm{M}\right)$ towards a limited panel of cancer cell lines.
\end{abstract}

Keywords: soft coral; Lobophytum varium; lobane; prenyleudesmane; anti-inflammatory activity

\section{Introduction}

Marine organisms have been well recognized as an important source of natural products with diverse chemical structures and wide array of bioactivities, including the anti-inflammatory activities [1-3]. Soft corals belonging to the genus Lobophytum (Alcyoniidae) are considered to be a rich source of diterpenoids [4-16] and steroids [17-22], of which some exerted cytotoxic [4-8,18,21,23], antibacterial $[4,8,10,11]$, antiviral [15], anti-acetylcholinesterase [9], and anti-inflammatory 
activities $[6,8,10,15,16,19]$. The terpenoid metabolites of cembrane-derived $[4-9,15,16]$, including their dimers [8,10], lobane-derived diterpenoids [11-14], and to a lesser extent of prenyleudesmane-based diterpenoids $[12,23,24]$, have been reported from soft corals belonging to the genus Lobophytum. Certain lobane diterpenoids exhibited an anti-inflammatory potential through different mechanisms such as reduction of cyclooxygenase-2 (COX-2) protein expression [25], inhibition of leukotriene synthesis [26], and suppression of 5-lipoxygenase (5-LOX) [27]. Our continuing investigation on the chemical constituents of soft corals belonging to the genus Lobophytum has led to the discovery of steroids, glycolipids, and cembranoids from L. mirabile [21], L. crassum [6,16,28], and L. sarcophytoides [19]. This study was aimed to isolate new metabolites from a Taiwanese soft coral L. varium and led to the discovery of five new diterpenes and seven known related compounds. Neutrophils play a critical role in the host defenses against invasion by pathogens and in the pathogenesis of various inflammatory diseases, such as rheumatoid arthritis. Activation of neutrophils by diverse stimuli results in secretion of a series of cytotoxins, reactive oxygen species (e.g., superoxide anion), and granule proteases (e.g., elastase) [29]. Therefore, agents which can suppress the excessive activation of neutrophils have been proposed to ameliorate the related inflammatory diseases. In this context, the anti-inflammatory activity of the isolated metabolites from L. varium was evaluated in vitro through measuring their ability to inhibit fMLP/CB-stimulated superoxide anion generation and elastase release in human neutrophils. This assay has been previously used by our group to disclose a number of marine diterpenoids possessing anti-inflammatory potential [30,31]. Moreover, the cytotoxicity against the growth of a limited panel of cancer cell lines was evaluated using Alamar Blue assay.

\section{Results and Discussion}

The solvent-free EtOAc extract of L. varium was primarily fractionated over a silica gel column. Further separation using a series of normal phase (NP) and reversed phase (RP) silica yielded five new diterpenoids lobovarols A-E (1-5, Figure 1) and seven known lobane diterpenoids (6-12, Figure 2). The chemical identities of the known compounds (6-12) were determined by comparison of their infrared (IR), mass spectrum (MS), and nuclear magnetic resonance (NMR) spectroscopic data with the published data and were found to be lobatriene (6) [32,33], lobatrienolide (7) [34], isofuscol (8) [24], fuscol (9) [35], 13,15-epoxyloba-8,10,16-trien-18-ol (10) [36], 17,18-epoxyloba-8,10,13(15)-trien-16-ol (11) $[13,14]$, and $(1 R, 2 R, 4 S, 17 R)-$ loba-8,10,13(15)-trien-17,18-diol (12) [12], respectively.

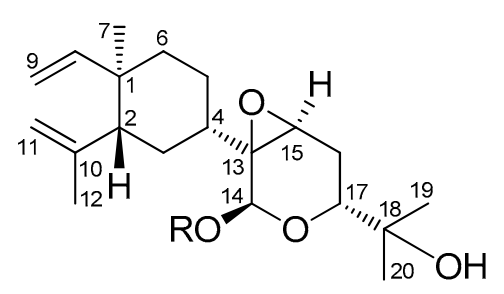

$1 \mathrm{R}=\mathrm{H}$

$2 \mathrm{R}=\mathrm{CH}_{3}$<smiles>C=C[C@H](CCC(=C)[C@H]1CC[C@@](C)(C=C)[C@H](C(C)C)C1)C(C)(C)O</smiles>

4<smiles>C=C[C@]1(C)CC[C@@H](C2=CC[C@@H](C(C)(C)O)O[C@@H]2OC)C[C@@H]1C</smiles>

3

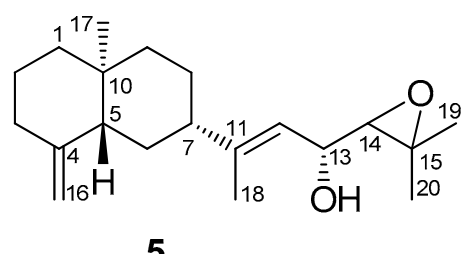

5

Figure 1. New diterpenoids isolated from Lobophytum varium. 


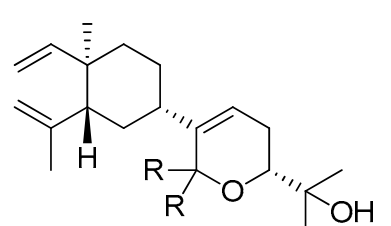

$6 \mathrm{R}=\mathrm{H}$ $7 \mathrm{R}, \mathrm{R}=\mathrm{O}$

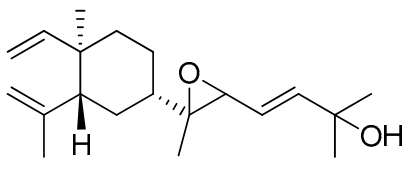

10<smiles>C=C[C@]1(C)CC[C@@H](C(C)(O)/C=C/C=C(C)C)C[C@H]1C(=C)C</smiles>

8<smiles>C=C[C@]1(C)CC[C@@H](/C(C)=C/[C@@H](O)C2OC2(C)C)C[C@@H]1C(=C)C</smiles>

11<smiles>C=C[C@]1(C)CC[C@@H](/C(C)=C/C=C/C(C)(C)O)C[C@H]1C(=C)C</smiles>

9<smiles>C=C[C@]1(C)CC[C@@H](/C(C)=C/C[C@H](O)C(C)(C)O)C[C@H]1C(=C)C</smiles>

12<smiles>C=C[C@]1(C)CC[C@@H](C(=C)C)C[C@H]1C(=C)C</smiles>

13<smiles>C=C1CCC[C@]2(C)CC[C@@H](C(=C)C)C[C@H]12</smiles>

14

Figure 2. Known diterpenoids (6-12) isolated from Lobophytum varium, $\beta$-elemene, and $\beta$-silenene.

Lobovarol A (1) was isolated as a colorless oil, $[\alpha]_{\mathrm{D}}^{25}-31.7$. The high-resolution electrospray ionization mass spectrometry (HRESIMS) $\left(m / z\right.$ 359.2191 $\left.[\mathrm{M}+\mathrm{Na}]^{+}\right)$and NMR data of $\mathbf{1}$ (Tables 1 and 2$)$ established the molecular formula of $\mathbf{1}$ as $\mathrm{C}_{20} \mathrm{H}_{32} \mathrm{O}_{4}$ with five degrees of unsaturation. The broad IR absorption band at $v_{\max } 3417 \mathrm{~cm}^{-1}$ was ascribed to hydroxy functionality. The ${ }^{13} \mathrm{C}$ NMR spectral data, measured in $\mathrm{CDCl}_{3}$ (Table 2) displayed twenty carbon signals, including those of four methyls, of a diterpenoid. The ${ }^{13} \mathrm{C}$ and ${ }^{1} \mathrm{H}$ NMR spectra of 1 revealed the presence of two olefins: a vinyl $\left(\delta_{\mathrm{C}} 149.6\right.$, $\mathrm{CH}$ and $110.2, \mathrm{CH}_{2} ; \delta_{\mathrm{H}} 5.78, \mathrm{dd}, J=17.6,10.4 \mathrm{~Hz}, 4.90 \mathrm{~d}, J=17.6 \mathrm{~Hz}$, and $4.90, \mathrm{br} \mathrm{d}, J=10.4 \mathrm{~Hz}$ ) and an isopropenyl $\left(\delta_{\mathrm{C}} 147.1, \mathrm{C}, 112.5, \mathrm{CH}_{2}\right.$ and $24.9, \mathrm{CH}_{3} ; \delta_{\mathrm{H}} 4.84$ and 4.60 , each $1 \mathrm{H}$, br s; and 1.70, 3H, s). Furthermore, a ring-junctured methyl $\left(\delta_{\mathrm{C}} 16.5, \mathrm{CH}_{3} ; \delta \mathrm{H} 0.99,3 \mathrm{H}, \mathrm{s}\right)$ and a methine $\left(\delta_{\mathrm{C}} 52.1, \mathrm{CH} ; \delta_{\mathrm{H}}\right.$ 1.94 , br dd, $J=9.2,6.0 \mathrm{~Hz}$ ) groups exhibited ${ }^{3} J_{\mathrm{CH}}$ heteronuclear multiple bond correlations (HMBC) to each other and designated a $\beta$-elemene (13) ring system $[12,13,37]$ in the molecule. These NMR signals are also characteristic for the lobane-type diterpenoids [11-14,25]. The presence of a trisubstituted epoxide $\left(\delta_{\mathrm{C}} 64.2, \mathrm{C}\right.$, and $\left.59.1, \mathrm{CH} ; \delta_{\mathrm{H}} 3.49, \mathrm{dd}, J=2.0,2.0 \mathrm{~Hz}\right)$, a dimethyl hydroxymethine $\left(\delta_{\mathrm{C}} 71.1\right.$, $\mathrm{C}, 26.5, \mathrm{CH}_{3}$, and $24.0, \mathrm{CH}_{3} ; \delta_{\mathrm{H}} 1.22$ and 1.13 , each $\left.3 \mathrm{H} \mathrm{s}\right)$, an oxymethine $\left(\delta_{\mathrm{C}} 68.3, \mathrm{CH} ; \delta_{\mathrm{H}} 3.45, \mathrm{dd}\right.$, $J=11.2,3.0 \mathrm{~Hz})$ and a dioxy-methine $\left(\delta_{\mathrm{C}} 89.5, \mathrm{CH} ; \delta_{\mathrm{H}} 5.30, \mathrm{~s}\right)$ were also confirmed in the side chain of the six-membered ring. Thus, an oxygen atom should form an ether-linkage at $\mathrm{C}-14\left(\delta_{\mathrm{C}} 89.5, \mathrm{CH}\right)$ and C-17 $\left(\delta_{\mathrm{C}} 68.3, \mathrm{CH}\right)$, which was confirmed by the HMBC correlations from H-14 $\left(\delta_{\mathrm{H}} 5.30, \mathrm{~s}\right)$ to C-17. Comparison of ${ }^{13} \mathrm{C}$ NMR spectral data of 1 with those of lobatrienolide (7) isolated from Sinularia flexibilis [34] and in this study, revealed the same carbon skeleton for both compounds. However, the carbonyl at C-14 $\left(\delta_{C} 164.7, C\right)$ and the trisubstituted double bond $\left(\delta_{C} 136.7, C, C-13\right.$ and 137.1, $\mathrm{CH}, \mathrm{C}-15)$ of 7 have been reduced to a hemiketal methine group $\left(\delta_{\mathrm{C}} 89.5, \mathrm{CH}, \mathrm{C}-14\right)$ and epoxidized $\left(\delta_{\mathrm{C}} 64.2, \mathrm{C}, \mathrm{C}-13\right.$ and 59.1, CH, C-15) in 1, respectively. Analysis of correlation spectroscopy (COSY) correlations of 1 established three consecutive proton spin systems extending from $\mathrm{H}-2$ to $\mathrm{H}_{2}-6, \mathrm{H}-8$ to $\mathrm{H}_{2}-9$, and $\mathrm{H}-15$ to $\mathrm{H}-17$ (Figure 3), which were connected by the key HMBC correlations observed from the angular methyl protons $\mathrm{H}_{3}-7\left(\delta_{\mathrm{H}} 0.99,3 \mathrm{H}, \mathrm{s}\right)$ to $\mathrm{C}-2, \mathrm{C}-6$, and $\mathrm{C}-8$, and from the olefinic methyl protons $\mathrm{H}_{3}-12\left(\delta_{\mathrm{H}} 1.70,3 \mathrm{H}, \mathrm{s}\right)$ to $\mathrm{C}-2$, and confirmed the $\beta$-elemene ring system. Moreover, HMBC correlations found from the hemiketal methine proton $\mathrm{H}-14\left(\delta_{\mathrm{H}} 5.30\right.$, s) to C-4, C-13, and C-17, from each of $\mathrm{H}_{3}-19$ and $\mathrm{H}_{3}-20\left(\delta_{\mathrm{H}} 1.13\right.$ and 1.22 , each $\left.3 \mathrm{H}, \mathrm{s}\right)$ to the oxymethine carbon $\mathrm{C}-17$ confirmed the ether linkage of the 2-hydroxypyran ring and the epoxide ring to be at C-14/C-17 and C-13/C-15, respectively. Thus, the planar structures of $\mathbf{1}$ was established as shown in Figure 3. 
Table 1. ${ }^{1} \mathrm{H}$ NMR spectral data for compounds $\mathbf{1 - 5 .}$

\begin{tabular}{|c|c|c|c|c|c|}
\hline$\#$ & $1^{a}$ & $2^{b}$ & $3^{a}$ & $4^{a}$ & $5^{b}$ \\
\hline 1 & - & - & - & - & $1.46 \mathrm{~m} ; 1.28 \mathrm{~m}$ \\
\hline 2 & $1.94 \mathrm{br}$ dd $(9.2,6.0)^{\mathrm{c}}$ & $1.95 \mathrm{dd}(6.0,6.0,3.0)$ & $2.02 \mathrm{dd}(12.4,4.0)$ & $2.00 \mathrm{~m}$ & $1.62,2 \mathrm{H}, \mathrm{m}$ \\
\hline 3 & $1.56,2 \mathrm{H}, \mathrm{m}$ & $1.59 \mathrm{~m} ; 1.49 \mathrm{~m}$ & $1.61 \mathrm{~m} ; 1.54 \mathrm{~m}$ & $1.54,2 \mathrm{H}, \mathrm{m}$ & $2.31 \mathrm{~d}(13.0) ; 2.01 \mathrm{~m}$ \\
\hline 4 & $1.56 \mathrm{~m}$ & $1.56 \mathrm{~m}$ & $2.00 \mathrm{~m}$ & $1.89 \mathrm{~m}$ & \\
\hline 5 & $1.64 \mathrm{~m} ; 1.36 \mathrm{~m}$ & $1.63 \mathrm{~m} ; 1.33 \mathrm{~m}$ & $1.64 \mathrm{~m} ; 1.49 \mathrm{~m}$ & $1.61 \mathrm{~m} ; 1.41 \mathrm{~m}$ & $1.83 \mathrm{~d}(12.0)$ \\
\hline 6 & $1.38-1.50,2 \mathrm{H}, \mathrm{m}$ & $1.46,2 \mathrm{H}, \mathrm{m}$ & $1.48,2 \mathrm{H}, \mathrm{m}$ & $1.46,2 \mathrm{H}, \mathrm{m}$ & $1.54 \mathrm{~m} ; 1.34 \mathrm{~m}$ \\
\hline 7 & $0.99,3 \mathrm{H}, \mathrm{s}$ & $0.983 \mathrm{H}, \mathrm{s}$ & $1.00,3 \mathrm{H}, \mathrm{s}$ & $1.00,3 \mathrm{H}, \mathrm{s}$ & $1.97 \mathrm{~m}$ \\
\hline 8 & $\begin{array}{c}5.78 \mathrm{dd} \\
(17.6,10.4)\end{array}$ & $\begin{array}{c}5.79 \mathrm{dd} \\
(18.0,10.5)\end{array}$ & $\begin{array}{c}5.82 \mathrm{dd} \\
(17.6,10.4)\end{array}$ & $\begin{array}{c}5.82 \mathrm{dd} \\
(18.0,10.8)\end{array}$ & $1.53 \mathrm{~m}, 1.28 \mathrm{~m}$ \\
\hline 9 & $\begin{array}{l}4.90 \mathrm{~d}(17.6) \\
4.90 \mathrm{~d}(10.4)\end{array}$ & $\begin{array}{c}4.90 \text { d (16); } \\
4.89 \text { d (13.5) }\end{array}$ & $\begin{array}{l}4.92 \mathrm{~d}(17.6) \\
4.91 \mathrm{~d}(10.4)\end{array}$ & $\begin{array}{l}4.92 \mathrm{~d}(16.4) \\
4.90 \mathrm{~d}(11.6)\end{array}$ & $1.52, \mathrm{~m} ; 1.28 \mathrm{~m}$ \\
\hline 11 & $4.84 \mathrm{br} \mathrm{s} ; 4.60 \mathrm{br} \mathrm{s}$ & $4.83 \mathrm{~s} ; 4.58 \mathrm{~s}$ & $\begin{array}{c}4.82 \text { dd }(1.6,1.6) \\
4.58 \text { br d }(1.6)\end{array}$ & $4.82 \mathrm{~s} ; 4.59 \mathrm{~s}$ & - \\
\hline 12 & $1.703 \mathrm{H}, \mathrm{s}$ & $1.703 \mathrm{H}, \mathrm{s}$ & $1.713 \mathrm{H}, \mathrm{s}$ & $1.71,3 \mathrm{H}, \mathrm{s}$ & $5.33 \mathrm{~d}(8.5)$ \\
\hline 13 & & & & & $4.25 \mathrm{dd}(8.5,8.0)$ \\
\hline 14 & $5.30 \mathrm{~s}$ & $4.91 \mathrm{~s}$ & $4.88 \mathrm{~s}$ & $4.82 \mathrm{~s} ; 4.74 \mathrm{~s}$ & $2.82 \mathrm{~d}(8.0)$ \\
\hline 15 & $3.49 \mathrm{dd}(2.0,2.0)$ & $3.30 \mathrm{br} \mathrm{s}$ & 5.73 br d (6.0) & $2.03,2 \mathrm{H}, \mathrm{m}$ & - \\
\hline 16 & $\begin{array}{l}2.04 \text { ddd }(14.8,2.4,2.4) \\
1.82 \text { ddd }(14.8,11.2,2.0)\end{array}$ & $\begin{array}{l}2.05 \text { ddd }(14.0,2.5,2.5) \\
1.84 \text { ddd }(14.0,12.0,2.5)\end{array}$ & $2.22 \mathrm{~m} ; 1.99 \mathrm{~m}$ & $1.75,2 \mathrm{H}, \mathrm{m}$ & $4.72 \mathrm{~s} ; 4.43 \mathrm{~s}$ \\
\hline 17 & $3.45 \mathrm{dd}(11.2,3.0)$ & $3.58 \mathrm{dd}(12,2.5)$ & $3.67 \mathrm{dd}(11.6,3.6)$ & $4.84 \mathrm{dd}(10.4,2.8)$ & $0.73,3 \mathrm{H}, \mathrm{s}$ \\
\hline 18 & - & - & - & - & $1.72,3 \mathrm{H}, \mathrm{s}$ \\
\hline 19 & $1.13,3 \mathrm{H}, \mathrm{s}$ & $1.14,3 \mathrm{H}, \mathrm{s}$ & $1.18,3 \mathrm{H}, \mathrm{s}$ & $1.21,3 \mathrm{H}, \mathrm{s}$ & $1.33,3 \mathrm{H}, \mathrm{s}$ \\
\hline 20 & $1.22,3 \mathrm{H}, \mathrm{s}$ & $1.25,3 \mathrm{H}, \mathrm{s}$ & $1.29,3 \mathrm{H}, \mathrm{s}$ & $1.22,3 \mathrm{H}, \mathrm{s}$ & $1.32,3 \mathrm{H}, \mathrm{s}$ \\
\hline $\mathrm{OMe}$ & - & $3.47,3 \mathrm{H}, \mathrm{s}$ & $3.463 \mathrm{H}, \mathrm{s}$ & - & - \\
\hline OAc & - & - & - & $2.13,3 \mathrm{H}, \mathrm{s}$ & - \\
\hline
\end{tabular}

Spectra recorded in $\mathrm{CDCl}_{3}$ at ${ }^{\mathrm{a}} 400$ and ${ }^{\mathrm{b}} 500 \mathrm{MHz}$ at $25^{\circ} \mathrm{C} .{ }^{\mathrm{c}} J$ values $(\mathrm{Hz})$ in parentheses.

Table 2. ${ }^{13} \mathrm{C}$ NMR data of compounds 1-5.

\begin{tabular}{|c|c|c|c|c|c|}
\hline \# & $1^{a}$ & $2^{b}$ & $3^{a}$ & $4^{a}$ & $5^{b}$ \\
\hline 1 & $39.7(\mathrm{C})$ & $39.7(\mathrm{C})$ & $39.7(\mathrm{C})$ & $39.8(\mathrm{C})$ & $41.9\left(\mathrm{CH}_{2}\right)$ \\
\hline 2 & $52.1(\mathrm{CH})^{c}$ & $52.0(\mathrm{CH})$ & $52.8(\mathrm{CH})$ & $52.8(\mathrm{CH})$ & $23.4\left(\mathrm{CH}_{2}\right)$ \\
\hline 3 & $28.7\left(\mathrm{CH}_{2}\right)$ & $28.9\left(\mathrm{CH}_{2}\right)$ & $34.1\left(\mathrm{CH}_{2}\right)$ & $33.3\left(\mathrm{CH}_{2}\right)$ & $36.9\left(\mathrm{CH}_{2}\right)$ \\
\hline 4 & $41.9(\mathrm{CH})$ & $41.8(\mathrm{CH})$ & $40.5(\mathrm{CH})$ & $44.4(\mathrm{CH})$ & $150.9(\mathrm{C})$ \\
\hline 5 & $22.8\left(\mathrm{CH}_{2}\right)$ & $22.9\left(\mathrm{CH}_{2}\right)$ & $26.4\left(\mathrm{CH}_{2}\right)$ & $27.2\left(\mathrm{CH}_{2}\right)$ & $49.9(\mathrm{CH})$ \\
\hline 6 & $39.1\left(\mathrm{CH}_{2}\right)$ & $39.2\left(\mathrm{CH}_{2}\right)$ & $39.8\left(\mathrm{CH}_{2}\right)$ & $40.0\left(\mathrm{CH}_{2}\right)$ & $29.2\left(\mathrm{CH}_{2}\right)$ \\
\hline 7 & $16.5\left(\mathrm{CH}_{3}\right)$ & $16.5\left(\mathrm{CH}_{3}\right)$ & $16.6\left(\mathrm{CH}_{3}\right)$ & $16.6\left(\mathrm{CH}_{3}\right)$ & $47.6(\mathrm{CH})$ \\
\hline 8 & $149.6(\mathrm{CH})$ & $149.8(\mathrm{CH})$ & $150.2(\mathrm{CH})$ & $150.2(\mathrm{CH})$ & $26.6\left(\mathrm{CH}_{2}\right)$ \\
\hline 9 & $110.2\left(\mathrm{CH}_{2}\right)$ & $110.1\left(\mathrm{CH}_{2}\right)$ & $109.9\left(\mathrm{CH}_{2}\right)$ & $109.9\left(\mathrm{CH}_{2}\right)$ & $41.0\left(\mathrm{CH}_{2}\right)$ \\
\hline 10 & $147.1(\mathrm{C})$ & $147.2(\mathrm{C})$ & $147.5(\mathrm{C})$ & $147.6(\mathrm{C})$ & $36.0(\mathrm{C})$ \\
\hline 11 & $112.5\left(\mathrm{CH}_{2}\right)$ & $112.4\left(\mathrm{CH}_{2}\right)$ & $112.2\left(\mathrm{CH}_{2}\right)$ & $112.1\left(\mathrm{CH}_{2}\right)$ & $146.1(\mathrm{C})$ \\
\hline 12 & $24.9\left(\mathrm{CH}_{3}\right)$ & $24.7\left(\mathrm{CH}_{3}\right)$ & $24.7\left(\mathrm{CH}_{3}\right)$ & $24.8\left(\mathrm{CH}_{3}\right)$ & $120.8(\mathrm{CH})$ \\
\hline 13 & $64.2(\mathrm{C})$ & $61.7(\mathrm{C})$ & $140.6(\mathrm{C})$ & $153.6(\mathrm{C})$ & $67.9(\mathrm{CH})$ \\
\hline 14 & $89.5(\mathrm{CH})$ & $97.7(\mathrm{CH})$ & $97.8(\mathrm{CH})$ & $107.5\left(\mathrm{CH}_{2}\right)$ & $67.5(\mathrm{CH})$ \\
\hline 15 & $59.1(\mathrm{CH})$ & $55.3(\mathrm{CH})$ & $121.1(\mathrm{CH})$ & $31.4\left(\mathrm{CH}_{2}\right)$ & $59.8(\mathrm{C})$ \\
\hline 16 & $24.8\left(\mathrm{CH}_{2}\right)$ & $25.2\left(\mathrm{CH}_{2}\right)$ & $24.8\left(\mathrm{CH}_{2}\right)$ & $28.1\left(\mathrm{CH}_{2}\right)$ & $105.4\left(\mathrm{CH}_{2}\right)$ \\
\hline 17 & $68.3(\mathrm{CH})$ & $69.5(\mathrm{CH})$ & $72.1(\mathrm{CH})$ & $79.7(\mathrm{CH})$ & $16.4(\mathrm{CH})$ \\
\hline 18 & $71.1(\mathrm{C})$ & $71.4(\mathrm{C})$ & $71.5(\mathrm{C})$ & $72.5(\mathrm{C})$ & $15.5\left(\mathrm{CH}_{3}\right)$ \\
\hline 19 & $24.0\left(\mathrm{CH}_{3}\right)$ & $24.5\left(\mathrm{CH}_{3}\right)$ & $24.4\left(\mathrm{CH}_{3}\right)$ & $24.9\left(\mathrm{CH}_{3}\right)$ & $24.9\left(\mathrm{CH}_{3}\right)$ \\
\hline 20 & $26.5\left(\mathrm{CH}_{3}\right)$ & $27.0\left(\mathrm{CH}_{3}\right)$ & $26.7\left(\mathrm{CH}_{3}\right)$ & $26.8\left(\mathrm{CH}_{3}\right)$ & $19.6\left(\mathrm{CH}_{3}\right)$ \\
\hline \multicolumn{2}{|c|}{ 14-OMe } & $55.6\left(\mathrm{CH}_{3}\right)$ & $55.4\left(\mathrm{CH}_{3}\right)$ & & \\
\hline \multicolumn{2}{|c|}{ 17-OAc } & & & $21.1\left(\mathrm{CH}_{3}\right)$ & \\
\hline
\end{tabular}

Spectra recorded in $\mathrm{CDCl}_{3}$ at ${ }^{\mathrm{a}} 100$ and ${ }^{\mathrm{b}} 125 \mathrm{MHz}$ at $25^{\circ} \mathrm{C} .{ }^{\mathrm{c}}$ Attached protons were determined by DEPT experiments. Values are presented as ppm downfield from TMS. 


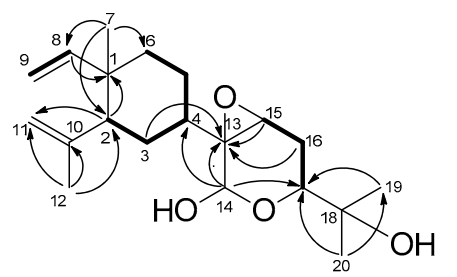

1

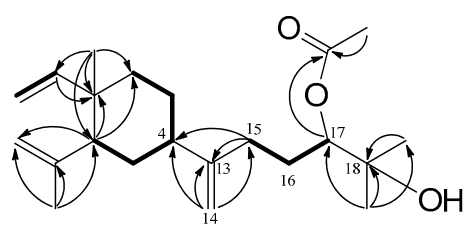

4

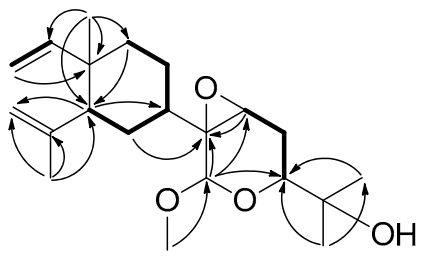

2

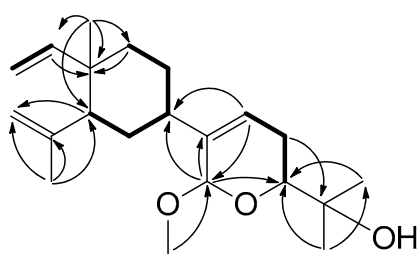

3

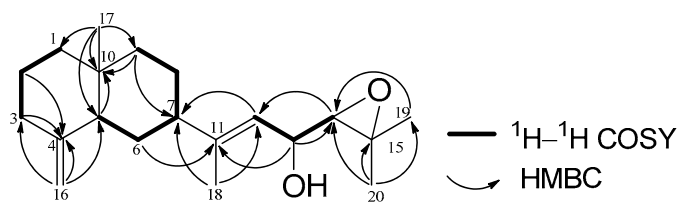

5

Figure 3. Key COSY and HMBC correlations of 1-5.

The relative configuration at the seven chiral centers of $\mathbf{1}$ was determined by the analysis of nuclear Overhauser effect (NOE) correlations along with molecular modeling using MM2 force field calculations (Figure 4). The nuclear Overhauser effect spectroscopy (NOESY) spectrum of compound 1 was remeasured in $\mathrm{C}_{6} \mathrm{D}_{6}$ for better resolution since the proton signals of $\mathrm{H}_{2}-3$ and $\mathrm{H}-4$ in $\mathrm{CDCl}_{3}$ were overlapped $(3 \mathrm{H}, 1.56, \mathrm{~m})$. In $\mathrm{C}_{6} \mathrm{D}_{6}$, NOE interactions were observed for $\mathrm{H}-4\left(\delta_{\mathrm{H}} 1.25, \mathrm{~m}\right)$ with H-2 $\left(\delta_{\mathrm{H}} 1.75, \mathrm{~m}\right), \mathrm{H}_{3}-7\left(\delta_{\mathrm{H}} 0.92,3 \mathrm{H}, \mathrm{s}\right)$ with $\mathrm{H}-6 \alpha\left(\delta_{\mathrm{H}} 1.22, \mathrm{~m}\right), \mathrm{H}-6 \beta\left(\delta_{\mathrm{H}} 1.33, \mathrm{~m}\right)$ with H-2. Furthermore, the similar $\delta_{\mathrm{C}}$ values of $\mathrm{C}-1, \mathrm{C}-2, \mathrm{C}-7$, and C-8 to C-12 of the previously-reported $\beta$-elemene and lobane-type diterpenoids [12,32-34], isolated from the same genus Lobophytum or prepared by enantiocontrolled synthesis [37], suggested the $1 R, 2 R, 4 S$-configuration in compound 1. Moreover, the $R$ configuration established for C-16 in the related lobane diterpenoids 11 (latter discussed) also implied the absolute configuration of chiral centers of the prenyleudesmane 5 and hence the lobanes 1-4. The NOE correlations observed for both $\mathrm{H}-3 \alpha\left(\delta_{\mathrm{H}} 1.50, \mathrm{~m}\right)$ and $\mathrm{H}-5 \alpha\left(\delta_{\mathrm{H}} 1.22, \mathrm{~m}\right)$ with $\mathrm{H}-14\left(\delta_{\mathrm{H}} 5.22, \mathrm{~s}\right)$, and for $\mathrm{H}-4$ with $\mathrm{H}-15\left(\delta_{\mathrm{H}} 3.03, \mathrm{dd}, J=2.0,1.6 \mathrm{~Hz}\right)$ indicated that the protons at C-14 and C-15 of the pyran ring should be syn to each other and were assigned arbitrarily as $\alpha$-oriented. In turn, $\mathrm{H}-15$ exhibited NOE interactions with both $\mathrm{H}_{2}-16$ protons $\left(\delta_{\mathrm{H}} 1.58\right.$, ddd, $J=13.2,11.2,2.0 \mathrm{~Hz}$, $\mathrm{H}-16 \alpha$ and $1.73, \mathrm{~m}, \mathrm{H}-16 \beta)$ while $\mathrm{H}-17$, which has an axial-axial coupling with $\mathrm{H}-16 \alpha(J=11.2 \mathrm{~Hz})$, displayed a significant NOE correlation with $\mathrm{H}-16 \beta$. Therefore, $\mathrm{H}-17$ should be $\beta$-configured. This was also suggested by the absence of NOE response of H-17 with $\mathrm{H}-14$. The above-mentioned NOEs found for $\mathrm{H}-14$ with $\mathrm{H}-3 \alpha$ and $\mathrm{H}-5 \alpha$, and for $\mathrm{H}-15$ with $\mathrm{H}-4$ revealed that the pyran ring should be perpendicular to the $\beta$-elemene ring system. To further prove the $\beta$-position of the epoxide ring, a conformation analysis using Chem3D, molecular mechanics calculations (MM2) and dihedral driving calculation were carried out [38,39]. The most stable (the lowest-energy) conformations for compound $\mathbf{1}$ and its 13,15-epimer $\mathbf{1 a}$ which possesses an $\alpha$-epoxide are represented in Figures 4 and 5, respectively. In this perspective, we focused on the calculated distances between the diagnostic proton pairs having key NOE correlations in conformer 1 , which were found shorter than $3.0 \AA$, in comparison with those calculated for 1a (Table 3). The results demonstrated that the $\beta$-configuration of the epoxide ring could only fulfill all described NOE correlations mentioned above. On the basis of the above findings, the $(1 R, 2 R, 4 S, 13 R, 14 R, 15 S, 17 R)$-configuration of 1 was, thus, established.

Lobovarol B (2) was also isolated as a colorless oil with a hydroxy group (IR $v_{\max } 3445 \mathrm{~cm}^{-1}$ ). The NMR data (Tables 1 and 2) showed the characteristic signals of lobane-type diterpenoids as in $\mathbf{1}$. Its HRESIMS $m / z 373.2350[\mathrm{M}+\mathrm{Na}]^{+}$and NMR data deduced a molecular formula $\mathrm{C}_{21} \mathrm{H}_{34} \mathrm{O}_{4}$ with a 14 mass unit difference from compound 1. Comparison of NMR data of compounds 2 and $\mathbf{1}$ revealed that compound 2 is the methyl ether of 1 due to the appearance of the methoxy signals $\left(\delta_{\mathrm{C}} 55.6, \mathrm{CH}_{3} ; \delta_{\mathrm{H}}\right.$ $3.47,3 \mathrm{H}, \mathrm{s})$. The HMBC correlation observed from the methoxy protons to the dioxymethine carbon $\left(\delta_{\mathrm{C}}\right.$ 
97.7, CH, C-14) designated the C-14 position of the methoxyl. Therefore, compound 2 was identified as the methyl acetal arising from methylation of $14-\mathrm{OH}$ of $\mathbf{1}$. The structure of $\mathbf{2}$ was further confirmed by the analysis of COSY and HMBC correlations (Figure 3). Moreover, compound 2 displayed analogous NOE correlations and possessed the same sign of optical rotation $\left([\alpha]_{D}^{25}-34.7\right)$ as those of $\mathbf{1}$, implying the same absolute configuration for both $\mathbf{1}$ and $\mathbf{2}$.

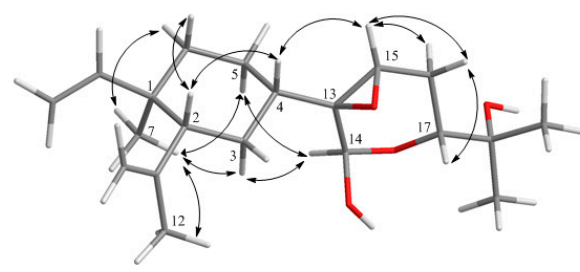

1

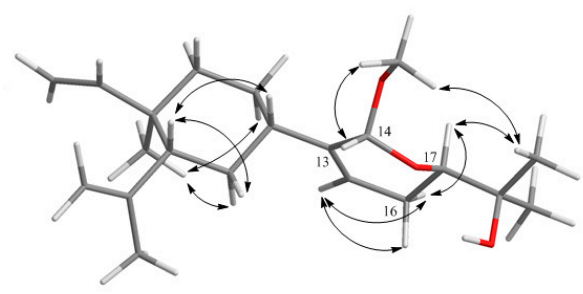

3

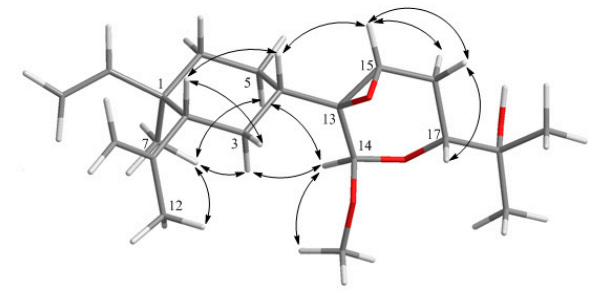

2

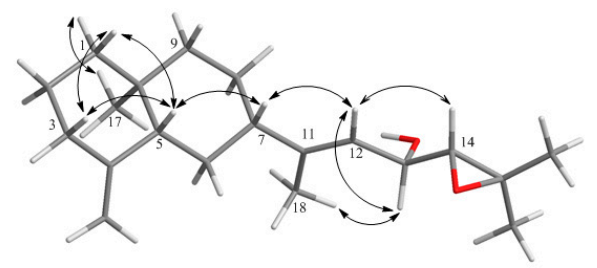

5

Figure 4. Key NOE correlations of $\mathbf{1 - 3}$ and $\mathbf{5}$.

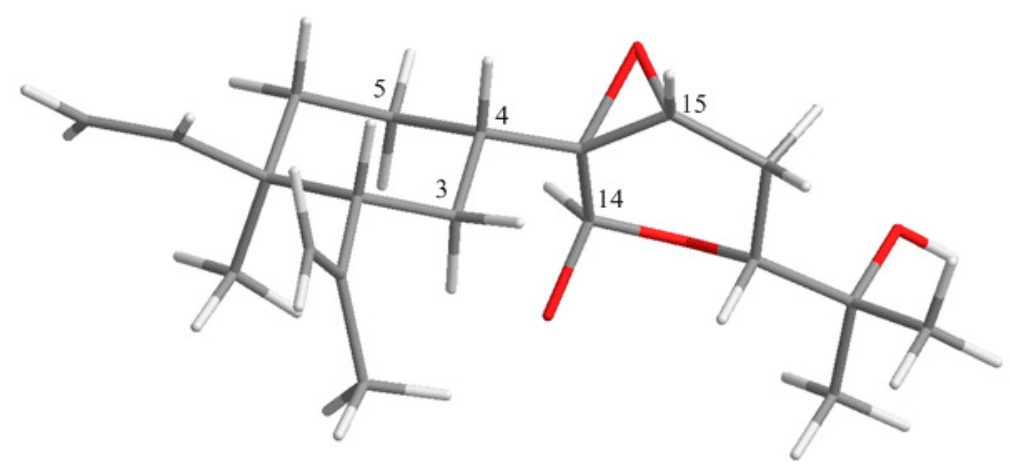

Figure 5. Molecular model of 1a.

Table 3. Calculated conformational energies as a function of the dihedral angle of $\mathrm{C}(3)-\mathrm{C}(4)-\mathrm{C}(13)-\mathrm{O}$ and the distances between the diagnostic protons of $\mathbf{1}$ and $\mathbf{1 a}$.

\begin{tabular}{ccc}
\hline Compound & 1 ( $\beta$-Epoxide) & 1a ( $\alpha$-Epoxide) \\
\hline Dihedral angle of $\mathrm{C}(3)-\mathrm{C}(4)-\mathrm{C}(13)-\mathrm{O}$ & $-80^{\circ}$ & $-150^{\circ}$ \\
\hline Minimum energy conformer $(\mathrm{Kcal} / \mathrm{mol})$ & 75.78 & 80.92 \\
\hline & Calculated distances \\
\hline $\mathrm{H}(4)-\mathrm{H}(15)$ & $2.45 \AA$ & $2.45 \AA$ \\
$\mathrm{H}(14)-\mathrm{H}(3 \alpha)$ & $2.54 \AA$ & $3.73 \AA$ \\
$\mathrm{H}(14)-\mathrm{H}(5 \alpha)$ & $2.30 \AA$ & $2.51 \AA$ \\
$\mathrm{H}(14)-\mathrm{H}(5 \beta)$ & $3.35 \AA$ & $2.79 \AA$ \\
\hline
\end{tabular}


Lobovarol C (3) was obtained as a colorless oil. Its sodium adduct ion peak $[\mathrm{M}+\mathrm{Na}]^{+}$at $\mathrm{m} / \mathrm{z}$ 357.2400 in the HRESIMS revealed a molecular formula of $\mathrm{C}_{21} \mathrm{H}_{34} \mathrm{O}_{3}$ which has one oxygen atom less than that of 2 . The IR absorption band at $v_{\max }$ of $3450 \mathrm{~cm}^{-1}$ again indicated the presence of a hydroxy functionality in the molecule. Again, careful inspection of the ${ }^{1} \mathrm{H}$ and ${ }^{13} \mathrm{C}$ NMR spectroscopic data (Tables 1 and 2) of 3 showed resonances and coupling constants identical to those of the $\beta$-elemene ring system, as verified in compounds $\mathbf{1}$ and $\mathbf{2}$ and other known lobane-type diterpenoids. Comparison of the 21 carbon signals of $\mathbf{3}$ with those of $\mathbf{2}$ showed that the trisubstituted epoxy signals in $\mathbf{2}$ was replaced by those of a trisubstituted double bond $\left(\delta_{\mathrm{C} /} \delta_{\mathrm{H}} 140.6, \mathrm{C} ; 121.1, \mathrm{CH} / 5.73, \mathrm{br} \mathrm{d}, J=6.0 \mathrm{~Hz}\right)$ in 3. The planar structure of $\mathbf{3}$ was further established by analyzing its COSY and HMBC correlations (Figure 3). Compound 3 exhibited NOE interactions consistent with $1 R, 2 R$, and $4 S$ configurations of the $\beta$-elemene ring system as in $\mathbf{1}$ and 2. Additionally, the oxymethine proton $\mathrm{H}-17\left(\delta_{\mathrm{H}} 3.67 \mathrm{dd}\right.$, $J=11.6,3.6 \mathrm{~Hz})$ was found to NOE interact with one of the isopropyl group at C-18 $\left(\delta_{\mathrm{H}} 1.29,3 \mathrm{H}, \mathrm{s}\right.$, $\mathrm{H}_{3}-20$ ) which, in turn, showed NOE correlation with the C-14 methoxyl protons. Thus, $\mathrm{H}-17$ and H-14 are anti to each other, as found in compounds $\mathbf{1}$ and $\mathbf{2}$ (Figure 4). Compound $\mathbf{3}$ was, thus, identified as $(1 R, 2 R, 4 S, 14 R, 17 R, 13 Z)-14,17-e p o x y-14-m e t h o x y l o b a-8,10,13(15)$-trien-18-ol.

The new metabolite lobovarol $\mathrm{D}(4)$ was found to have a molecular formula $\mathrm{C}_{22} \mathrm{H}_{36} \mathrm{O}_{3}$ as deduced from its HRESIMS $\left(\mathrm{m} / z 371.2557[\mathrm{M}+\mathrm{H}]^{+}\right)$and NMR data (Tables 1 and 2), implying five degrees of unsaturation. The IR absorptions at 3450 and $1735 \mathrm{~cm}^{-1}$ further indicated the presence of both hydroxy and ester functionalities. The NMR data revealed that compound 4 is another lobane diterpenoid possessing a $\beta$-elemene ring system and a side chain with an acetoxy, an exomethylene, and a tertiary hydroxyl. Analysis of the COSY spectrum of 4 revealed three consecutive protons systems $\left(\mathrm{H}-8 / \mathrm{H}_{2}-9\right.$, $\mathrm{H}-2$ to $\mathrm{H}_{2}-6$, and $\mathrm{H}_{2}-15$ to $\left.\mathrm{H}-17\right)$. The connectivities of these three partial structures, as well as the location of the acetoxy, exomethylene, and the tertiary hydroxy groups, were established by inspection of the ${ }^{2} J_{\mathrm{CH}}$ and ${ }^{3} J_{\mathrm{CH}}$ correlations found in the HMBC spectra (Figure 3). The ${ }^{2} J_{\mathrm{CH}}$ and ${ }^{3} J_{\mathrm{CH}}$ correlations observed from the tertiary $\mathrm{H}_{3}-19\left(\delta_{\mathrm{H}} 1.21,3 \mathrm{H}, \mathrm{s}\right)$ and $\mathrm{H}_{3}-20\left(\delta_{\mathrm{H}} 1.22,3 \mathrm{H}, \mathrm{s}\right)$ to the $s p^{3}$ non-protonated oxycarbon $\left(\delta_{C} 72.5, C, C-18\right)$ and the oxymethine carbon $\left(\delta_{C} 79.7, \mathrm{CH}, \mathrm{C}-17\right)$ positioned the hydroxy and acetoxy groups at $\mathrm{C}-18$ and $\mathrm{C}-17$, respectively. Further, the HMBC correlations found from the olefinic protons $\left(\delta_{\mathrm{H}} 4.82\right.$, and 4.74 , each $\left.1 \mathrm{H}, \mathrm{s}\right)$ to $\mathrm{C}-4\left(\delta_{\mathrm{C}} 44.4, \mathrm{CH}\right), \mathrm{C}-13\left(\delta_{\mathrm{C}} 153.6, \mathrm{C}\right)$, and $\mathrm{C}-15\left(\delta_{\mathrm{C}}\right.$ $31.4, \mathrm{CH}_{2}$ ) indicated the $\mathrm{C}-13$ location of the exomethylene group. These results established the gross structure of 4 (Figure 3). Analysis of NOE correlations again determined the $1 R, 2 R, 4 S$ configuration of 4. However, the $\mathrm{C}-17$ configuration remains unresolved, although according to the related biosynthetic pathway, 4 might possess the same 17R configuration as those of 1-3.

Lobovarol E (5) was obtained as a white powder. The molecular formula was deduced to be $\mathrm{C}_{20} \mathrm{H}_{32} \mathrm{O}_{2}$ as indicated by the HRESIMS $\left(\mathrm{m} / z\right.$ 327.2292 $\left.[\mathrm{M}+\mathrm{Na}]^{+}\right)$and NMR data (Tables 1 and 2), implying five degrees of unsaturation. Its IR absorption band at $3422 \mathrm{~cm}^{-1}$ revealed the presence of a hydroxy functionality, which was further supported by the NMR signals at $\delta_{C} 67.9$ and $\delta_{\mathrm{H}} 4.25$. The NMR data (Tables 1 and 2 ) showed the presence of one 1,1-disubstitued $\left(\delta_{C} 150.9, C\right.$ and 105.4 $\mathrm{CH}_{2} ; \delta_{\mathrm{H}} 4.72$ and 4.43 , each $\left.1 \mathrm{H}, \mathrm{s}\right)$ and a trisubstituted $\left(\delta_{\mathrm{C}} 146.1, \mathrm{C}\right.$ and $120.8, \mathrm{CH} ; \delta_{\mathrm{H}} 5.33,1 \mathrm{H}, \mathrm{d}$, $J=8.5 \mathrm{~Hz})$ olefinic bonds, a trisubstituted epoxide $\left(\delta_{\mathrm{C}} 59.8, \mathrm{C} ; 67.5, \mathrm{CH} ; \delta_{\mathrm{H}} 2.82,1 \mathrm{H}, \mathrm{d}, J=8.0 \mathrm{~Hz}\right)$, and a hydroxyl-bearing methine $\left(\delta_{\mathrm{C}} 67.9, \mathrm{CH} ; \delta_{\mathrm{H}} 4.25,1 \mathrm{H}, \mathrm{dd}, J=8.5,8.0 \mathrm{~Hz}\right)$. One olfeinic methyl $\left(\delta_{\mathrm{H}} 1.72\right.$, $3 \mathrm{H}, \mathrm{s})$, and three tertiary methyls $\left(\delta_{\mathrm{H}} 1.33,1.32\right.$, and 0.73 , each $\left.3 \mathrm{H}, \mathrm{s}\right)$, were also identified. Therefore, the compound was suggested to have a bicyclic structure to fulfill the five degrees of unsaturation. The bicyclic structure of $\mathbf{5}$ was found to be the same as that of one eudesmene from the nearly the same NMR data of positions 1 to 10,16, and 17 of 5 with the corresponding sesquiterpene (14) [40]. From the COSY correlations of 5 (Figure 3), three partial structures consecutive proton systems extended from $\mathrm{H}_{2}-1$ to $\mathrm{H}_{2}-3, \mathrm{H}-5$ to $\mathrm{H}_{2}-9$, and $\mathrm{H}-12$ to $\mathrm{H}-14$ were established. Analysis of HMBC correlations of 5 led to the establishment of its planar structure. It was also found that the key HMBC correlations observed from both $\mathrm{H}_{3}-19$ and $\mathrm{H}_{3}-20$ to the epoxide carbons $\mathrm{C}-14\left(\delta_{\mathrm{C}} 67.5, \mathrm{CH}\right)$ and $\mathrm{C}-15\left(\delta_{\mathrm{C}} 59.8\right.$, C) and from the hydroxymethine $\mathrm{H}-13\left(\delta_{\mathrm{H}} 4.25, \mathrm{dd}, J=8.5,8.0 \mathrm{~Hz}\right)$ to $\mathrm{C}-11\left(\delta_{\mathrm{C}} 146.1, \mathrm{C}\right)$ and $\mathrm{C}-14$ demonstrated the positions of the epoxide and the hydroxyl to be at C-14/C-15 and C-13, respectively. 
This was further proved by the matched chemical shifts of ${ }^{1} \mathrm{H}$ and ${ }^{13} \mathrm{C}$ atoms of the side chain of $\mathbf{5}$ with the correspondent atoms of the known compound 17,18-epoxyloba-8,10,13(15)-trien-16-ol (11) [13] which was also isolated in this study. Therefore, the prenyleudesmane molecular structure of 5 was established as illustrated in Figure 3.

The relative configuration of 5 was determined by analyzing the NOE correlations in the NOESY spectrum, as well as a lowest energy stable conformation generated using MM2 calculation (Figure 4). The NOE interactions of $\mathrm{H}-5$ with $\mathrm{H}-7$, but not with $\mathrm{H}_{3}-17$, reflected the $5 R^{*}, 7 S^{*}, 10 S^{*}$-configuration. The NOE correlations displayed for the $\beta$-oriented $\mathrm{H}-7$ with the olefinic proton $\mathrm{H}-12$, but not with $\mathrm{H}_{3}-18$, disclosed the $E$ geometry of the 11,12 -double bond. The $\alpha$-orientation of the hydroxyl at $\mathrm{C}-13$ was suggested by the NOE correlations of $\mathrm{H}-12 / \mathrm{H}-13$ and $\mathrm{H}-12 / \mathrm{H}-7$, as shown in a molecular model in Figure 4. The NOE correlations of $\mathrm{H}-12 / \mathrm{H}-7$ and $\mathrm{H}_{3}-18 / \mathrm{H}-13$ proved the $E$-geometry of $\mathrm{C}-11 / \mathrm{C}-12$ double bond. The above finding and other detailed NOE correlations (Figure 4) established the relative stereochemistry of 5 . The relative configuration at chiral carbons C-13 was further suggested by that correspondent to C-16 of the known biogenetically related metabolite $\mathbf{1 1}$ which has been also isolated from the same organism in this study. Fortunately, the larger quantity of compound $\mathbf{1 1}$ enabled us to determine the absolute configuration of $\mathbf{1 1}$ and hence that of $\mathbf{5}$, through the esterification of 16-hydroxy group in 11 by Mosher's method [41,42]. Analysis of the calculated $\Delta \delta_{H}\left(\delta_{S}-\delta_{R}\right)$ values of protons neighboring C-16 of the prepared (S)- and (R)-2-methoxy-2-(trifluoromethyl)-2-phenylacetic (MTPA) esters (11a and 11b, Figure 6) led to the assignment of the $R$ configuration at C-16 in $\mathbf{1 1}$ and consequently the correspondent $13 R$ configuration in 5 . On the basis of the above findings, the absolute configuration of 5 was established as $5 R, 7 S, 10 S, 13 R$. However, the stereochemistry at C-14 remained undetermined in spite of the NOE correlation of $\mathrm{H}-14 / \mathrm{H}-12$.

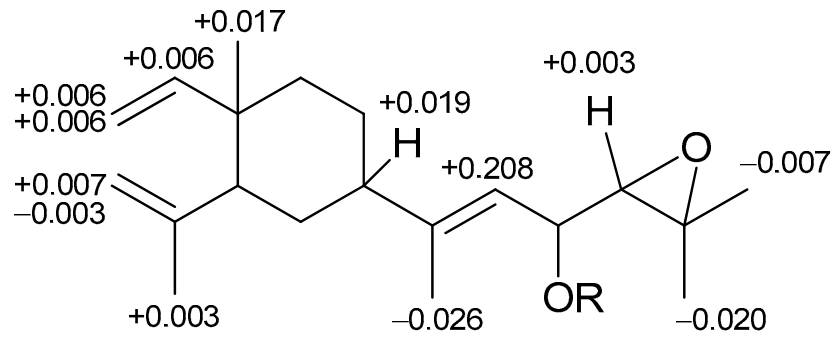

11: $\mathrm{R}=\mathrm{H}$

11a: $R=(S)-M T P A$

11b: $\mathrm{R}=(R)-\mathrm{MTPA}$

Figure 6. ${ }^{1} \mathrm{H}$ NMR chemical shift differences $\Delta \delta\left(\delta_{S}-\delta_{R}\right)$ in ppm for the MTPA esters of $\mathbf{1 1}$.

The cytotoxic activity of the isolated compounds (1-12) were screened against human lung adenocarcinoma (A549), human prostatic carcinoma (LN-cap), and human colon adenocarcinoma (DLD-1) cell lines using the Alamar Blue assay. The results showed that these compounds are not cytotoxic toward the three cancer cell lines.

Since many lobane diterpenoids were reported to exhibit anti-inflammatory activity through different mechanisms [25-27], the isolated metabolites in this study were evaluated for their anti-inflammatory potential through measuring their ability to suppress fMLP/CB-induced superoxide anion generation and elastase release in human neutrophils. The results (Figure 7) demonstrated that compounds 2, 5, and 11 expressed a moderate inhibitory effect $(22.08 \pm 4.71,20.59 \pm 2.15$, and $28.16 \pm 5.06 \%$, respectively) at $10 \mu \mathrm{M}$ against superoxide anion generation in fMLP/CB-stimulated cells. Moreover, compounds 5, 8, 11, and 12 were found to be more active in inhibiting the elastase release ( $33.94 \pm 5.85$ to $45.34 \pm 4.08 \%$ ) than compounds $\mathbf{2}, \mathbf{4}, \mathbf{9}$, and $\mathbf{1 0}$ which exhibited a moderate activity (23.07 \pm 6.55 to $28.44 \pm 5.28 \%)$ at $10 \mu \mathrm{M}$. The weak inhibition against elastase release was exerted by compounds $3, \mathbf{6}$, and $7(11.40 \pm 1.28$ to $15.14 \pm 2.52 \%)$. It is noteworthy to mention that although compounds $\mathbf{5}$ and $\mathbf{1 1}$ possessed the same side chain, it seems that the ring system of $\beta$-elemene in $\mathbf{1 1}$ has a role in increasing the anti-inflammatory effect relative to $\beta$-selinene moiety. 
Moreover, except for compound 2, other lobane diterpenoids possessing a pyran ring in their side chain $(\mathbf{1}, \mathbf{3}, \mathbf{6}$, and $\mathbf{7})$ showed weaker activity against elastase release in the fMLP/CB-stimulated neutrophils.

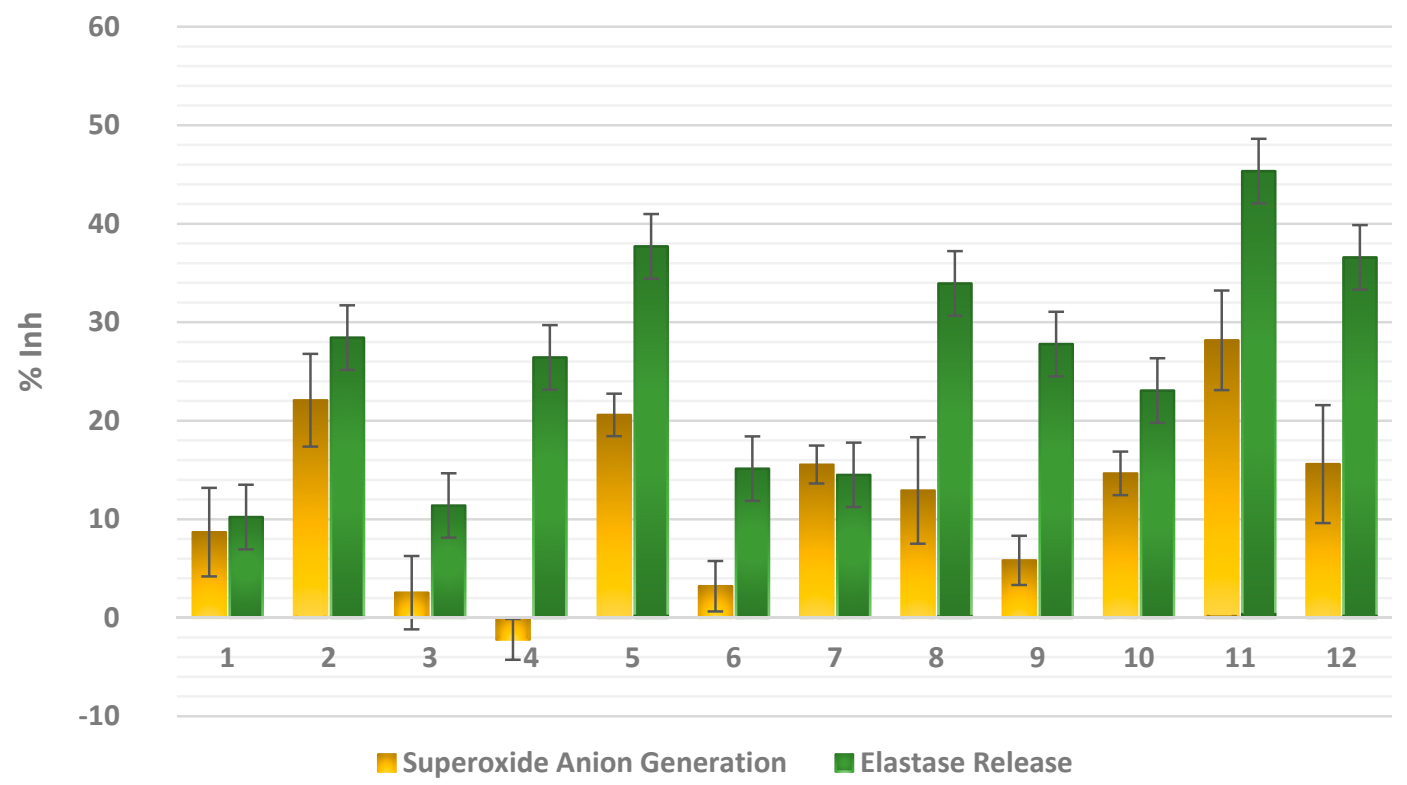

Figure 7. Inhibitory effects (\% Inh) of compounds 1-12 at $10 \mu \mathrm{M}$ on superoxide anion generation and elastase release by human neutrophils in response to $N$-formyl-L-methionyl-leucyl-phenylalanine/cytochalasin B (FMLP/CB). Results are presented as the mean \pm S.E.M $(n=3-4)$.

\section{Materials and Methods}

\subsection{General Procedures}

Optical rotations were measured on a JASCO P-1020 polarimeter (Jasco Corporation, Tokyo, Japan). IR spectra were recorded on a JASCO FT/IR-4100 spectrophotometer (Jasco). ESIMS and HRESIMS data were performed on a BRUKER APEX II mass (Bruker, Bremen, Germany) spectrometers. The NMR spectra were recorded on a Varian Unity INOVA 500 FT-NMR (Varian Inc., Palo Alto, CA, USA) at $500 \mathrm{MHz}$ for ${ }^{1} \mathrm{H}$ and $125 \mathrm{MHz}$ for ${ }^{13} \mathrm{C}$ or on a Varian $400 \mathrm{FT}-\mathrm{NMR}$ (Varian Inc.) at $400 \mathrm{MHz}$ for ${ }^{1} \mathrm{H}$ and $100 \mathrm{MHz}$ for ${ }^{13} \mathrm{C}$ in $\mathrm{CDCl}_{3}$ or $\mathrm{C}_{6} \mathrm{D}_{6}$ using TMS as internal standard ( $\delta$ in ppm, $J$ in Hz). Silica gel 60 (230-400 mesh, Merck, Darmstadt, Germany) pre-coated silica gel plates (Merck, Kieselgel 60 F254, $0.2 \mathrm{~mm}$ ) were used for open CC and analytical TLC analysis, respectively. Isolation by HPLC was performed by a Hitachi L-2455 instrument (Hitachi Ltd., Tokyo, Japan) equipped with a reversed-phase (RP-18) column (ODS-3, $5 \mu \mathrm{m}, 250 \times 20$ mm, Sciences Inc., Tokyo, Japan).

\subsection{Animal Material}

The soft coral Lobophytum varium Tixier-Durivault was collected by hand via SCUBA at a depth of $10-15 \mathrm{~m}$ from Jihui Fish Port, Taitung, Taiwan $\left(23^{\circ} 7^{\prime} 2^{\prime \prime} \mathrm{N}, 121^{\circ} 23^{\prime} 49.2^{\prime \prime} \mathrm{E}\right)$, in March 2013, and stored at $-20^{\circ} \mathrm{C}$ until extraction. The organism was identified by Professor Chang-Feng Dai, Institute of Oceanography, National Taiwan University, Taipei 112, Taiwan.

\subsection{Extraction and Separation}

The frozen bodies of L. varium (1.3 kg, wet weight) were sliced and exhaustively extracted with EtOAc. The solvent-free extract $(55.4 \mathrm{~g}$ ) was fractionated by silica gel column chromatography, using EtOAc in $n$-hexane $(0.0$ to $100 \%)$ then acetone in EtOAc $(0.0$ to $100 \%)$ as eluting solvents, to yield 24 fractions (F1 to F24). F8 eluted with 4.8\% EtOAc in $n$-hexane was further purified in a silica gel column using EtOAc- $n$-hexane (1:10) to give two major subfractions F81 and F82. The subfractions 
were separately purified by NP-HPLC silica gel using 20\% EtOAc in $n$-hexane and RP-HPLC silica gel using $\mathrm{CH}_{3} \mathrm{CN}-\mathrm{H}_{2} \mathrm{O}(3: 2)$ to yield $10(1.8 \mathrm{mg})$ and $\mathbf{1}(2.8 \mathrm{mg})$, respectively. F9, eluted with $6.5 \%$ EtOAc in $n$-hexane, was initially purified in a silica gel column, using EtOAc- $n$-hexane (1:6), and then was isolated by RP-HPLC using MeOH to yield $8(0.9 \mathrm{mg})$. F11, eluted with $9 \%$ EtOAc in $n$-hexane, was further fractionated successively in Sephadex LH-20 and RP-silica gel columns using $\mathrm{MeOH}$ and $\mathrm{MeOH}-\mathrm{H}_{2} \mathrm{O}$ (3:1), respectively, to afford three subfractions, F111 to F113. The fractions were purified separately by RP-HPLC using $\mathrm{MeOH}-\mathrm{H}_{2} \mathrm{O}$ (3:1, 4:1, and 5:1) to give 7 (1.8 mg), 2 (1.1 mg), and 6 $(1.5 \mathrm{mg})$, respectively. F12, eluted with $11.5 \%$ EtOAc in $n$-hexane, was primarily purified by silica gel chromatography using EtOAc- $n$-hexane (1:10) and then separated by RP-HPLC using $\mathrm{MeOH}-\mathrm{H}_{2} \mathrm{O}$ (8:1) to yield $3(3.5 \mathrm{mg})$ and $9(3.0 \mathrm{mg})$. Moreover, F15, eluted with 20\% EtOAc in $n$-hexane, was re-chromatographed in a silica gel column using EtOAc- $n$-hexane (1:5), and then by RP-HPLC using $\mathrm{MeOH}-\mathrm{H}_{2} \mathrm{O}(5: 1)$ to afford $4(2.8 \mathrm{mg})$. F18, eluted with 50\% EtOAc in $n$-hexane, was initially refined in a silica gel column using EtOAc- $n$-hexane $(1: 5$,$) then further isolated on RP-HPLC using \mathrm{MeOH}-\mathrm{H}_{2} \mathrm{O}$ (5:1) to yield $\mathbf{1 1}(11 \mathrm{mg}), \mathbf{1 2}(6.1 \mathrm{mg})$, and $\mathbf{5}(2.6 \mathrm{mg})$.

\subsubsection{Lobovarol A (1)}

Colorless oil; $[\alpha]_{\mathrm{D}}^{25}-31.7$ (c 0.70, $\left.\mathrm{CHCl}_{3}\right)$; IR (neat) $v_{\max } 3417,3081,2925,2856,1639,1561,1377$, $1033 \mathrm{~cm}^{-1} ;{ }^{1} \mathrm{H}$ NMR $\left(400 \mathrm{MHz}, \mathrm{CDCl}_{3}\right)$ and ${ }^{13} \mathrm{C}\left(100 \mathrm{MHz}, \mathrm{CDCl}_{3}\right)$ data, see Tables 1 and 2, respectively; ${ }^{13} \mathrm{C}\left(100 \mathrm{MHz}, \mathrm{C}_{6} \mathrm{D}_{6}\right) \delta_{\mathrm{C}} 150.0(\mathrm{CH}, \mathrm{C}-8), 147.2(\mathrm{C}, \mathrm{C}-10), 112.8\left(\mathrm{CH}_{2}, \mathrm{C}-11\right), 110.3\left(\mathrm{CH}_{2}, \mathrm{C}-9\right), 89.9(\mathrm{CH}$, C-14), 70.8 (C, C-18), 68.4 (CH, C-17), 64.2 (C, C-13), 58.8 (CH, C-15), 52.1 (CH, C-2), 41.9 (CH, C-4), $39.9(\mathrm{C}, \mathrm{C}-1), 39.3\left(\mathrm{CH}_{2}, \mathrm{C}-6\right), 28.9\left(\mathrm{CH}_{2}, \mathrm{C}-3\right), 26.5\left(\mathrm{CH}_{3}, \mathrm{C}-20\right), 25.1\left(\mathrm{CH}_{2}, \mathrm{C}-16\right), 25.0\left(\mathrm{CH}_{3}, \mathrm{C}-12\right), 24.6$ $\left(\mathrm{CH}_{3}, \mathrm{C}-19\right), 23.0\left(\mathrm{CH}_{2}, \mathrm{C}-5\right), 16.6\left(\mathrm{CH}_{3}, \mathrm{C}-7\right) ;{ }^{1} \mathrm{H}$ NMR $\left(400 \mathrm{MHz}, \mathrm{C}_{6} \mathrm{D}_{6}\right) \delta_{\mathrm{H}} 5.73(1 \mathrm{H}, \mathrm{dd}, J=17.2,10.8$ $\mathrm{Hz}, \mathrm{H}-8), 5.22(1 \mathrm{H}, \mathrm{s}, \mathrm{H}-14), 4.92(1 \mathrm{H}, \mathrm{d}, J=17.2 \mathrm{~Hz}, \mathrm{H}-9 \beta), 4.90(1 \mathrm{H}, \mathrm{d}, J=10.8 \mathrm{~Hz}, \mathrm{H}-9 \alpha), 4.89(1 \mathrm{H}, \mathrm{s}$, $\mathrm{H}-11 \beta), 4.66(1 \mathrm{H}, \mathrm{s}, \mathrm{H}-11 \alpha), 3.37(1 \mathrm{H}, \mathrm{dd}, J=11.2,3.2 \mathrm{~Hz}, \mathrm{H}-17), 3.03(1 \mathrm{H}, \mathrm{dd}, J=2.0,1.6 \mathrm{~Hz}, \mathrm{H}-15), 1.75$ $(1 \mathrm{H}, \mathrm{m}, \mathrm{H}-2), 1.73(1 \mathrm{H}, \mathrm{m}, \mathrm{H}-16 \beta), 1.68\left(3 \mathrm{H}, \mathrm{s}, \mathrm{H}_{3}-12\right), 1.58(1 \mathrm{H}, \mathrm{ddd}, J=13.2,11.2,2.0 \mathrm{~Hz}, \mathrm{H}-16 \alpha), 1.53$ $(1 \mathrm{H}, \mathrm{m}, \mathrm{H}-3 \beta), 1.50(1 \mathrm{H}, \mathrm{m}, \mathrm{H}-3 \alpha), 1.48(1 \mathrm{H}, \mathrm{m}, \mathrm{H}-5 \beta), 1.33(1 \mathrm{H}, \mathrm{m}, \mathrm{H}-6 \beta), 1.25(1 \mathrm{H}, \mathrm{m}, \mathrm{H}-4), 1.22(2 \mathrm{H}$, $\mathrm{m}, \mathrm{H}-5 \alpha$ and $\mathrm{H}-6 \alpha), 1.19\left(3 \mathrm{H}, \mathrm{s}, \mathrm{H}_{3}-20\right), 1.05\left(3 \mathrm{H}, \mathrm{s}, \mathrm{H}_{3}-19\right), 0.92\left(3 \mathrm{H}, \mathrm{s}, \mathrm{H}_{3}-7\right)$; ESIMS $m / z 359[\mathrm{M}+\mathrm{Na}]^{+}$ and $375[\mathrm{M}+\mathrm{K}]^{+}$; HRESIMS $m / z 359.2191[\mathrm{M}+\mathrm{Na}]^{+}$(calcd. for $\mathrm{C}_{20} \mathrm{H}_{32} \mathrm{O}_{4} \mathrm{Na}, 359.2193$ ).

\subsubsection{Lobovarol B (2)}

Colorless oil; $[\alpha]_{\mathrm{D}}^{25}-34.7$ (c $0.28, \mathrm{CHCl}_{3}$ ); IR (neat) $v_{\max } 3445,3079,2925,2857,1641,1539$, 1374, $1048 \mathrm{~cm}^{-1} ;{ }^{1} \mathrm{H}$ NMR $\left(500 \mathrm{MHz}, \mathrm{CDCl}_{3}\right)$ and ${ }^{13} \mathrm{C}\left(125 \mathrm{MHz}, \mathrm{CDCl}_{3}\right)$ data, see Tables 1 and 2, respectively; ESIMS $m / z 373[\mathrm{M}+\mathrm{Na}]^{+}$and $389\left[\mathrm{M}+\mathrm{K}^{+} ;\right.$HRESIMS $m / z 373.2350[\mathrm{M}+\mathrm{Na}]^{+}$(calcd. for $\mathrm{C}_{21} \mathrm{H}_{34} \mathrm{O}_{4} \mathrm{Na}$, 373.2349).

\subsubsection{Lobovarol C (3)}

Colorless oil; $[\alpha]_{\mathrm{D}}^{25}-19.6\left(\right.$ c $\left.0.88, \mathrm{CHCl}_{3}\right)$; IR (neat) $v_{\max } 3450,3080,2927,2865,1639,1459$, 1374, $1045 \mathrm{~cm}^{-1} ;{ }^{1} \mathrm{H}$ NMR $\left(400 \mathrm{MHz}, \mathrm{CDCl}_{3}\right)$ and ${ }^{13} \mathrm{C}\left(100 \mathrm{MHz}, \mathrm{CDCl}_{3}\right)$ data, see Tables 1 and 2, respectively; ESIMS $m / z 357[\mathrm{M}+\mathrm{Na}]^{+}$and $373[\mathrm{M}+\mathrm{K}]^{+} ;$HRESIMS $m / z 357.2400[\mathrm{M}+\mathrm{Na}]^{+}$(calcd. for $\left.\mathrm{C}_{21} \mathrm{H}_{34} \mathrm{O}_{4} \mathrm{Na}, 357.2400\right)$.

\subsubsection{Lobovarol D (4)}

Colorless oil; $[\alpha]_{\mathrm{D}}^{25}+12.3\left(c 0.70, \mathrm{CHCl}_{3}\right.$ ); IR (neat) $v_{\max } 3450,3080,2924,2857,1735,1641$, $1458,1459,1373,1242,1041 \mathrm{~cm}^{-1} ;{ }^{1} \mathrm{H}$ NMR $\left(400 \mathrm{MHz}, \mathrm{CDCl}_{3}\right)$ and ${ }^{13} \mathrm{C}\left(100 \mathrm{MHz}, \mathrm{CDCl}_{3}\right)$ data, see Tables 1 and 2, respectively; ESIMS m/z $371[\mathrm{M}+\mathrm{Na}]^{+} ;$HRESIMS $m / z 371.2557\left[\mathrm{M}+\mathrm{Na}^{+}\right.$(calcd. for $\mathrm{C}_{21} \mathrm{H}_{34} \mathrm{O}_{4} \mathrm{Na}$, 371.2557). 


\subsubsection{Lobovarol E (5)}

White amorphous powder; $[\alpha]_{\mathrm{D}}^{25}-12.7\left(c \mathrm{c} .65, \mathrm{CHCl}_{3}\right)$; IR (neat) $v_{\max } 3422,3080,2927,2864$, $1648,1453,1380,1245,1057 \mathrm{~cm}^{-1} ;{ }^{1} \mathrm{H}$ NMR $\left(500 \mathrm{MHz}, \mathrm{CDCl}_{3}\right)$ and ${ }^{13} \mathrm{C}\left(125 \mathrm{MHz}, \mathrm{CDCl}_{3}\right)$ data, see Tables 1 and 2, respectively; ESIMS $m / z 327[\mathrm{M}+\mathrm{Na}]^{+}$; HRESIMS $m / z 327.2292[\mathrm{M}+\mathrm{Na}]^{+}$(calcd. for $\mathrm{C}_{21} \mathrm{H}_{34} \mathrm{O}_{4} \mathrm{Na}$, 327.2295).

\subsubsection{Preparation of (S)- and (R)-MTPA Esters of $\mathbf{1 1}$}

To a solution of $11 \mathrm{a}(2.0 \mathrm{mg})$ in pyridine $(100 \mu \mathrm{L}), R-(-)$-MTPA chloride $(5 \mu \mathrm{L})$ was added and allowed to react overnight at RT. The reaction was terminated by the addition of $1.0 \mathrm{~mL}$ of water, and then processed as previously described [43] to yield the (S)-MTPA ester 11a (0.4 mg, 19\%). Similarly, the correspondent $(R)$-MTPA ester 11 was also obtained from the reaction of $S-(+)$-MTPA chloride with 11 to give $11 \mathrm{~b}(0.2,11 \%) .{ }^{1} \mathrm{H}$ NMR $\left(\mathrm{CDCl}_{3}, 400 \mathrm{MHz}\right)$ of $11 \mathrm{a}: \delta_{\mathrm{H}} 5.819(1 \mathrm{H}, \mathrm{dd}, J=18.0,10.8 \mathrm{~Hz}, \mathrm{H}-8)$, $5.631(1 \mathrm{H}, \mathrm{dd}, J=10.0,8.4 \mathrm{~Hz}, \mathrm{H}-16), 5.3665(1 \mathrm{H}, \mathrm{d}, J=10 \mathrm{~Hz}, \mathrm{H}-15), 4.9225(1 \mathrm{H}, \mathrm{dd}, J=18.0,1.2 \mathrm{~Hz}$, H-9b), $4.920(1 \mathrm{H}, \mathrm{dd}, J=10.8,1.2 \mathrm{~Hz}, \mathrm{H}-9 \mathrm{a}), 4.849(1 \mathrm{H}, \mathrm{dd}, J=2.0,2.0 \mathrm{~Hz}, \mathrm{H}-11 \mathrm{~b}), 4.593(1 \mathrm{H}, \mathrm{s}, \mathrm{H}-11 \mathrm{a})$, $3.0005(1 \mathrm{H}, \mathrm{dd}, J=8.4,3.2 \mathrm{~Hz}, \mathrm{H}-17), 2.0195(1 \mathrm{H}, \mathrm{m}, \mathrm{H}-4), 1.8325\left(3 \mathrm{H}, \mathrm{d}, J=1.2 \mathrm{~Hz}, \mathrm{H}_{3}-14\right), 1.7205(3 \mathrm{H}$, $\left.\mathrm{d}, J=0.4 \mathrm{~Hz}, \mathrm{H}_{3}-12\right), 1.343\left(3 \mathrm{H}, \mathrm{s}, \mathrm{H}_{3}-20\right), 1.328\left(3 \mathrm{H}, \mathrm{s}, \mathrm{H}_{3}-19\right), 1.020\left(3 \mathrm{H}, \mathrm{s}, \mathrm{H}_{3}-7\right) ;{ }^{1} \mathrm{H} \mathrm{NMR}\left(\mathrm{CDCl}_{3}\right.$, $400 \mathrm{MHz})$ of $11 \mathrm{~b}: \delta_{\mathrm{H}} 5.813(1 \mathrm{H}, \mathrm{dd}, J=18.0,10.8 \mathrm{~Hz}, \mathrm{H}-8), 5.597(1 \mathrm{H}, \mathrm{dd}, J=10.0,8.4 \mathrm{~Hz}, \mathrm{H}-16), 5.1585$ $(1 \mathrm{H}, \mathrm{d}, J=10 \mathrm{~Hz}, \mathrm{H}-15), 4.9165(1 \mathrm{H}, \mathrm{dd}, J=18.0,1.2 \mathrm{~Hz}, \mathrm{H}-9 \mathrm{~b}), 4.914(1 \mathrm{H}, \mathrm{br} \mathrm{d}, J=12.0 \mathrm{~Hz}, \mathrm{H}-9 \mathrm{a}), 4.852$ (1H, br s, H-11b), 4.586 (1H, s, H-11a), 2.9975 (1H, br d, J = 8.4 Hz, H-17), 2.0004 (1H, m, H-4), 1.8585 (3H, $\left.\mathrm{d}, J=1.2 \mathrm{~Hz}, \mathrm{H}_{3}-14\right), 1.718\left(3 \mathrm{H}, \mathrm{s}, \mathrm{H}_{3}-12\right), 1.363\left(3 \mathrm{H}, \mathrm{s}, \mathrm{H}_{3}-20\right), 1.335\left(3 \mathrm{H}, \mathrm{s}, \mathrm{H}_{3}-19\right), 1.003\left(3 \mathrm{H}, \mathrm{s}, \mathrm{H}_{3}-7\right)$.

\subsection{Cytotoxicity Assay}

Cancer cell (A549, LN-cap, and DLD-1) lines were purchased from the American Type Culture Collection (ATCC). Alamar Blue assay [44,45] protocol was used to evaluate the cytotoxicity for the isolated metabolites from L. varium.

\subsection{In Vitro Anti-Inflammatory Assay}

Human neutrophils were obtained from whole blood using dextran sedimentation and Ficoll centrifugation. Purified neutrophils were resuspended in a $\mathrm{Ca}^{2+}$-free HBSS buffer (pH 7.4) at $4{ }^{\circ} \mathrm{C}$ prior to use.

\subsubsection{Measurement of Superoxide Anion Generation}

The production of superoxide anion was assayed by the method based on the superoxide oxide dismutase inhibitable reduction of ferricytochrome c [46,47]. Briefly, neutrophils incubated with ferricytochrome c $(0.5 \mathrm{mg} / \mathrm{mL})$ and $\mathrm{Ca}^{2+}(1 \mathrm{mM})$ were equilibrated at $37^{\circ} \mathrm{C}$ for $2 \mathrm{~min}$ and then treated with different concentrations of the tested compounds for $5 \mathrm{~min}$. Cells were activated by $100 \mathrm{nM}$ fMLP for $10 \mathrm{~min}$ in the pretreatment of cytochalasin B (CB, $1 \mu \mathrm{g} / \mathrm{mL}$ ) for $3 \mathrm{~min}$ (fMLP/CB).

\subsubsection{Measurement of Elastase Release}

The elastase release was assayed using MeO-Suc-Ala-Ala-Pro-Val-p-nitroanilide as substrate [46]. Briefly, neutrophils incubated with MeO-Suc-Ala-Ala-Pro-Val-p-nitroanilide $(100 \mu \mathrm{M})$ were equilibrated at $37^{\circ} \mathrm{C}$ and then treated with the tested compounds for $5 \mathrm{~min}$. Cells were then activated with fMLP $(100 \mathrm{nM}) / \mathrm{CB}(0.5 \mu \mathrm{g} / \mathrm{mL})$ for $10 \mathrm{~min}$.

\section{Conclusions}

The ethyl acetate extract of a Taiwanese soft coral Lobophytum varium was chemically investigated for the first time and led to the discovery of four new lobane-based (1-4), and one new prenyleudesmane-type (5), diterpenoids, along with seven known related metabolites (6-12). The establishment of the absolute configuration of $\mathbf{1 1}$ was achieved by Mosher's esterification. 
The evaluation of anti-inflammatory activity showed that diterpenoids $\mathbf{2}, \mathbf{5}$, and $\mathbf{1 1}$ possess moderate inhibitory activity on the generation of superoxide anion, while 5, 8, 11, and 12 could effectively suppress elastase released after stimulation of human neutrophils by fMLP/CB. The active metabolites might be considered as promising leads in the development of anti-inflammatory drugs.

Supplementary Materials: HRESIMS, ${ }^{1} \mathrm{H}$, and ${ }^{13} \mathrm{C}$ spectra of new compounds $\mathbf{1 - 5}$ are available online at $\backslash$ unhbox \voidb@x \hbox\{www.mdpi.com/1660-3397/15/10/300/s1\}. Figure S1. HRESIMS spectrum of 1; Figure S2. ${ }^{1} \mathrm{H}$ NMR spectrum of $\mathbf{1}$ in $\mathrm{C}_{6} \mathrm{D}_{6}$ at $400 \mathrm{MHz}$; Figure $\mathrm{S} 3 .{ }^{13} \mathrm{C}$ NMR spectrum of $\mathbf{1}$ in $\mathrm{C}_{6} \mathrm{D}_{6}$ at $100 \mathrm{MHz}$; Figure S4. HRESIMS spectrum of 2; Figure S5. ${ }^{1} \mathrm{H}$ NMR spectrum of 2 in $\mathrm{CDCl}_{3}$ at $500 \mathrm{MHz}$; Figure S6. ${ }^{13} \mathrm{C}$ NMR spectrum of $\mathbf{2}$ in $\mathrm{CDCl}_{3}$ at $125 \mathrm{MHz}$; Figure S7. HRESIMS spectrum of 3; Figure S8. ${ }^{1} \mathrm{H}$ NMR spectrum of $\mathbf{3}$ in $\mathrm{CDCl}_{3}$ at $400 \mathrm{MHz}$; Figure S9. ${ }^{13} \mathrm{C}$ NMR spectrum of 3 in $\mathrm{CDCl}_{3}$ at $100 \mathrm{MHz}$; Figure S10. HRESIMS spectrum of 4; Figure S11. ${ }^{1} \mathrm{H}$ NMR spectrum of 4 in $\mathrm{CDCl}_{3}$ at $400 \mathrm{MHz}$; Figure S12. ${ }^{13} \mathrm{C}^{\mathrm{NMR}}$ spectrum of 4 in $\mathrm{CDCl}_{3}$ at $100 \mathrm{MHz}$; Figure S13. HRESIMS spectrum of 5; Figure S14. ${ }^{1} \mathrm{H}$ NMR spectrum of 5 in $\mathrm{CDCl}_{3}$ at $500 \mathrm{MHz}$; Figure S15. ${ }^{13} \mathrm{C}$ NMR spectrum of 5 in $\mathrm{CDCl}_{3}$ at $125 \mathrm{MHz}$.

Acknowledgments: This work was supported mainly by grants from Ministry of Science and Technology (MOST 105-2113-M-110-002 and NSC-102-2113-M-110-001-MY2) awarded to J.-H.S. The authors extend their appreciation to the Deanship of Scientific Research at King Saud University for funding this work through research group no. RGP-VPP-272.

Author Contributions: Jyh-Horng Sheu designed and guided the whole experiment. Atallah F. Ahmed contributed to structure elucidation. Wan-Ting Teng isolated the compounds and performed data acquisition and structure elucidation. Chiung-Yao Huang performed the structure elucidation and cytotoxicity assay. Tsong-Long Hwang performed the anti-inflammatory assays. Atallah F. Ahmed and Jyh-Horng Sheu wrote the manuscript.

Conflicts of Interest: The authors declare no conflict of interest.

\section{References}

1. Blunt, J.W.; Copp, B.R.; Keyzers, R.A.; Munro, M.H.G.; Prinsep, M.R. Marine natural products. Nat. Prod. Rep. 2017, 34, 235-294. [CrossRef] [PubMed]

2. Cheung, R.C.; Ng, T.B.; Wong, J.H.; Chen, Y.; Chan, W.Y. Marine natural products with anti-inflammatory activity. Appl. Microbiol. Biotechnol. 2016, 100, 1645-1666. [CrossRef] [PubMed]

3. Wei, W.C.; Sung, P.J.; Duh, C.Y.; Chen, B.W.; Sheu, J.H.; Yang, N.S. Anti-inflammatory activities of natural products isolated from soft corals of Taiwan between 2008 and 2012. Mar. Drugs 2013, 11, 4083-4126. [CrossRef] [PubMed]

4. Zhao, M.; Yin, J.; Jiang, W.; Ma, M.; Lei, X.; Xiang, Z.; Dong, J.; Huang, K.; Yan, P. Cytotoxic and antibacterial cembranoids from a South China Sea soft coral, Lobophytum sp. Mar. Drugs 2013, 11, 1162-1172. [CrossRef] [PubMed]

5. Wang, S.K.; Duh, C.Y. New cytotoxic cembranolides from the soft coral Lobophytum michaelae. Mar. Drugs 2012, 10, 306-318. [CrossRef] [PubMed]

6. Kao, C.Y.; Su, J.H.; Lu, M.C.; Hwang, T.L.; Wang, W.H.; Chen, J.J.; Sheu, J.H.; Kuo, Y.H.; Weng, C.F.; Fang, L.S.; et al. Lobocrassins A-E: New cembrane-type diterpenoids from the soft coral Lobophytum crassum. Mar. Drugs 2011, 9, 1319-1331. [CrossRef] [PubMed]

7. Lee, N.L.; Su, J.H. Tetrahydrofuran cembranoids from the cultured soft coral Lobophytum crassum. Mar. Drugs 2011, 9, 2526-2536. [CrossRef] [PubMed]

8. Yan, P.; Deng, Z.; van Ofwegen, L.; Proksch, P.; Lin, W. Lobophytones H-N, biscembranoids from the Chinese soft coral Lobophytum pauciflorum. Chem. Pharm. Bull. 2010, 58, 1591-1595. [CrossRef] [PubMed]

9. Bonnard, I.; Jhaumeer-Laulloo, S.B.; Bontemps, N.; Banaigs, B.; Aknin, M. New lobane and cembrane diterpenes from two comorian soft corals. Mar. Drugs 2010, 8, 359-372. [CrossRef] [PubMed]

10. Yan, P.; Deng, Z.; van Ofwegen, L.; Proksch, P.; Lin, W. Lobophytones O-T, new biscembranoids and cembranoid from soft coral Lobophytum pauciflorum. Mar. Drugs 2010, 8, 2837-2848. [CrossRef] [PubMed]

11. Edrada, R.A.; Proksch, P.; Wray, V.; Witte, L.; van Ofwegen, L. Four new bioactive lobane diterpenes of the soft coral Lobophytum pauciflorum from Mindoro, Philippines. J. Nat. Prod. 1998, 61, 358-361. [CrossRef] [PubMed]

12. Dunlop, R.W.; Wells, R.J. Isolation of some novel diterpenes from a soft coral of the Genus Lobophytum. Aust. J. Chem. 1979, 32, 1345-1351. [CrossRef] 
13. Lakshmana Raju, B.; Subbaraju, G.V.; Bheemasankara Rao, C.; Trimurtulu, G. Two new oxygenated lobanes from a soft coral of Lobophytum species of the Andaman and Nicobar coasts. J. Nat. Prod. 1993, 56, 961-966. [CrossRef]

14. Anjaneyulu, A.S.R.; Venkateswara Rao, G.; Raju, K.V.S.; Murthy, M.V.R.K. Two new lobane derivatives from the soft coral Lobophytum pauciflorum of the Havelock Island of the Indian Ocean. Indian J. Chem. 1995, 34B, 1074-1079. [CrossRef]

15. Rashid, M.A.; Gustafson, K.R.; Boyd, M.R. HIV-inhibitory cembrane derivatives from a Philippines collection of the soft coral Lobophytum species. J. Nat. Prod. 2000, 63, 531-533. [CrossRef] [PubMed]

16. Chao, C.-H.; Wen, Z.-H.; Wu, Y.-C.; Yeh, H.-C.; Sheu, J.-H. Cytotoxic and Anti-inflammatory Cembranoids from the Soft Coral Lobophytum crassum. J. Nat. Prod. 2008, 71, 1819-1824. [CrossRef] [PubMed]

17. Hegazy, M.E.; Mohamed, T.A.; Elshamy, A.I.; Hassanien, A.A.; Abdel-Azim, N.S.; Shreadah, M.A.; Abdelgawad, I.I.; Elkady, E.M.; Pare, P.W. A new steroid from the Red Sea soft coral Lobophytum lobophytum. Nat. Prod. Res. 2016, 30, 340-344. [CrossRef] [PubMed]

18. Morris, L.A.; Christie, E.M.; Jaspars, M.; van Ofwegen, L.P. A bioactive secosterol with an unusual A- and B-ring oxygenation pattern isolated from an Indonesian soft coral Lobophytum sp. J. Nat. Prod. 1998, 61, 538-541. [CrossRef] [PubMed]

19. Lu, Y.; Lin, Y.-C.; Wen, Z.-H.; Su, J.-H.; Sung, P.-J.; Hsu, C.-H.; Kuo, Y.-H.; Chiang, M.Y.; Dai, C.-F.; Sheu, J.-H. Steroid and cembranoids from the Dongsha atoll soft coral Lobophytum sarcophytoides. Tetrahedron 2010, 66, 7129-7135. [CrossRef]

20. Rama Rao, M.; Venkatesham, U.; Reddy, M.V.R.; Venkateswarlu, Y. An unusual novel $C_{29}$ steroid from the soft coral Lobophytum crassum. J. Nat. Prod. 1999, 62, 785-786. [CrossRef] [PubMed]

21. Sheu, J.-H.; Yeh, T.-H. Isolation of a Bioactive Sterol from the Soft Coral Lobophytum Mirabile. J. Chin. Chem. Soc. 1991, 38, 397-399. [CrossRef]

22. Tursch, B.; Hootele, C.; Kaisin, M.; Losman, D.; Karlsson, R. Chemical studies of marine invertebrates. XVI. Structure and absolute configuration of lobosterol, a novel polyoxygenated sterol from the alcyonacean Lobophytum pauciflorum (coelenterata, octocorallia). Steroids 1976, 27, 137-142. [CrossRef]

23. Li, L.; Sheng, L.; Wang, C.Y.; Zhou, Y.B.; Huang, H.; Li, X.B.; Li, J.; Mollo, E.; Gavagnin, M.; Guo, Y.W. Diterpenes from the Hainan soft coral Lobophytum cristatum Tixier-Durivault. J. Nat. Prod. 2011, 74, 2089-2094. [CrossRef] [PubMed]

24. Coll, J.C.; Bowden, B.F.; König, G.M.; Braslau, R.; Price, I.R. Studies of Australian soft corals. XXXX.1 The natural products chemistry of Alcyonacean soft corals with special reference to the genus Lobophytum. Bull. Soc. Chim. Belg. 1986, 95, 815-834. [CrossRef]

25. Cheng, S.Y.; Chuang, C.T.; Wang, S.K.; Wen, Z.H.; Chiou, S.F.; Hsu, C.H.; Dai, C.F.; Duh, C.Y. Antiviral and anti-inflammatory diterpenoids from the soft coral Sinularia gyrosa. J. Nat. Prod. 2010, 73, 1184-1187. [CrossRef] [PubMed]

26. Shin, J.; Fenical, W. Fuscosides A-D: Anti-inflammatory diterpenoid glycosides of new structural classes from the caribbean gorgonian Eunicea fusca. J. Org. Chem. 1991, 56, 3153-3158. [CrossRef]

27. Kerr, R.G.; Brophy, S.; Derksen, D.J. Synthesis and evaluation of anti-inflammatory activity of derivatives of the marine natural products fuscol and eunicol. Bioorg. Med. Chem. Lett. 2014, 24, 4804-4806. [CrossRef] [PubMed]

28. Chao, C.H.; Huang, H.C.; Wu, Y.C.; Lu, C.K.; Dai, C.F.; Sheu, J.H. Glycolipids from the Formosan soft coral Lobophytum crassum. Chem. Pharm. Bull. 2007, 55, 1720-1723. [CrossRef] [PubMed]

29. Hwang, T.L.; Yeh, S.H.; Leu, Y.L.; Chern, C.Y.; Hsu, H.C. Inhibition of superoxide anion and elastase release in human neutrophils by 3'-isopropoxychalcone via a cAMP-dependent pathway. Br. J. Pharmacol. 2006, 148, 78-87. [CrossRef] [PubMed]

30. Lee, Y.N.; Tai, C.J.; Hwang, T.L.; Sheu, J.H. Krempfielins J-M, new eunicellin-based diterpenoids from the soft coral Cladiella krempfi. Mar. Drugs 2013, 11, 2741-2750. [CrossRef] [PubMed]

31. Huang, C.Y.; Ahmed, A.F.; Su, J.H.; Sung, P.J.; Hwang, T.L.; Chiang, P.L.; Dai, C.F.; Liaw, C.C.; Sheu, J.H. Bioactive new withanolides from the cultured soft coral Sinularia brassica. Bioorg. Med. Chem. Lett. 2017, 27, 3267-3271. [CrossRef] [PubMed]

32. Kusumi, T.; Hamada, T.; Ishitsuka, M.; Ohtani, I.; Kakisawa, H. Elucidation of the relative and absolute stereochemistry of lobatriene, a marine diterpene, by a modified Mosher method. J. Org. Chem. 1992, 57, 1033-1035. [CrossRef] 
33. Govindam, S.V.; Yoshioka, Y.; Kanamoto, A.; Fujiwara, T.; Okamoto, T.; Ojika, M. Cyclolobatriene, a novel prenylated germacrene diterpene, from the soft coral Lobophytum pauciflorum. Bioorg. Med. Chem. 2012, 20, 687-692. [CrossRef] [PubMed]

34. Hamada, T.; Kusumi, T.; Ishitsuka, M.O.; Kakisawa, H. Structures and absolute configurations of new lobane diterpenoids from the Okinawan soft coral Sinularia flexibilis. Chem. Lett. 1992, 21, 33-36. [CrossRef]

35. Gopichand, Y.; Schmitz, F.J. Marine natural products: Fuscol, a new elemene-type diterpene alcohol from the gorgonian Eunicea fusca. Tetrahedron Lett. 1978, 39, 3641-3644. [CrossRef]

36. Babu, U.V.; Bhandari, S.P.S.; Garg, H.S. Diterpenes from the soft coral Lobophytum pauciflorum of Indian coast. Indian J. Chem. 1998, 37B, 576-578.

37. Corey, E.J.; Roberts, B.E.; Dixon, B.R. Enantioselective total synthesis of $\beta$-elemene and fuscol based on enantiocontrolled Ireland-Claisen rearrangement. J. Am. Chem. Soc. 1995, 117, 193-196. [CrossRef]

38. CambridgeSoft. CS Chem3D 9.0 (Molecular Modeling and Analysis Standard); CambridgeSoft Inc.: Cambridge, MA, USA, 2004. Available online: http://www.cambridgesoft.com/support/DesktopSupport/ Documentation/Manuals / files / chem3d_9_english.pdf (accessed on 28 September 2017).

39. Charifson, P.S.; Bowen, J.P.; Wyrick, S.D.; Hoffman, A.J.; Cory, M.; McPhail, A.T.; Mailman, R.B. Conformational analysis and molecular modeling of 1-phenyl-, 4-phenyl-, and 1-benzyl-1,2,3,4tetrahydroisoquinolines as D1 dopamine receptor ligands. J. Med. Chem. 1989, 32, 2050-2058. [CrossRef] [PubMed]

40. Williams, H.J.; Sattler, I.; Moyna, G.; Scott, A.I.; Bell, A.A.; Vinson, S.B. Diversity in cyclic sesquiterpene production by Gossypium hirsutum. Phytochemistry 1995, 40, 1633-1636. [CrossRef]

41. Ohtani, I.; Kusumi, T.; Kashman, Y.; Kakisawa, H. High-Field FT NMR application of Mosher's Method. The absolute configurations of marine terpenoids. J. Am. Chem. Soc. 1991, 113, 4092-4096. [CrossRef]

42. Randazzo, A.; Bifulco, G.; Giannini, C.; Bucci, M.; Debitus, C.; Cirino, G.; Gomez-Paloma, L. Halipeptins $\mathrm{A}$ and B: Two novel potent anti-inflammatory cyclic depsipeptides from the Vanuatu marine sponge Haliclona species. J. Am. Chem. Soc. 2001, 123, 10870-10876. [CrossRef] [PubMed]

43. Huang, H.C.; Ahmed, A.F.; Su, J.H.; Chao, C.H.; Wu, Y.C.; Chiang, M.Y.; Sheu, J.H. Crassolides A-F, cembranoids with a trans-fused lactone from the soft coral Sarcophyton crassocaule. J. Nat. Prod. 2006, 69, 1554-1559. [CrossRef] [PubMed]

44. O'Brien, J.; Wilson, I.; Orton, T.; Pognan, F. Investigation of the Alamar Blue (resazurin) fluorescent dye for the assessment of mammalian cell cytotoxicity. Eur. J. Biochem. 2000, 267, 5421-5426. [CrossRef] [PubMed]

45. Nakayama, G.R.; Caton, M.C.; Nova, M.P.; Parandoosh, Z. Assessment of the Alamar Blue assay for cellular growth and viability in vitro. J. Immunol. Methods 1997, 204, 205-208. [CrossRef]

46. Yang, S.C.; Chung, P.J.; Ho, C.M.; Kuo, C.Y.; Hung, M.F.; Huang, Y.T.; Chang, W.Y.; Chang, Y.W.; Chan, K.H.; Hwang, T.L. Propofol inhibits superoxide production, elastase release, and chemotaxis in formyl peptide-activated human neutrophils by blocking formyl peptide receptor 1. J. Immunol. 2013, 190, 6511-6519. [CrossRef] [PubMed]

47. Yu, H.P.; Hsieh, P.W.; Chang, Y.J.; Chung, P.J.; Kuo, L.M.; Hwang, T.L. 2-(2-Fluorobenzamido)benzoate ethyl ester (EFB-1) inhibits superoxide production by human neutrophils and attenuates hemorrhagic shock-induced organ dysfunction in rats. Free Radic. Biol. Med. 2011, 50, 1737-1748. [CrossRef] [PubMed]

(C) 2017 by the authors. Licensee MDPI, Basel, Switzerland. This article is an open access article distributed under the terms and conditions of the Creative Commons Attribution (CC BY) license (http://creativecommons.org/licenses/by/4.0/). 